\title{
The effect of selected risk factors, including the mode of delivery, on the development of allergic rhinitis and bronchial asthma
}

\author{
Edyta Krzych-Fałta ${ }^{1}$, Konrad Furmańczyk ${ }^{1,2}$, Mira Lisiecka-Biełanowicz ${ }^{1}$, Adam Sybilski ${ }^{1,3}$, Aneta Tomaszewska ${ }^{1}$, \\ Filip Raciborski ${ }^{1}$, Oksana Wojas ${ }^{1}$, Artur Walkiewicz ${ }^{1}$, Piotr Samel-Kowalik', Bolesław Samoliński ${ }^{1}$
}

\begin{abstract}
${ }^{1}$ Unit of Environmental Hazard Prevention and Allergology, Faculty of Health Science, Medical University of Warsaw, Warsaw, Poland ${ }^{2}$ Chair of Applied Mathematics, Faculty of Applied Informatics and Mathematics, Warsaw University of Life Sciences (SGGW), Warsaw, Poland

${ }^{3}$ Department of Pediatrics and Neonatology, Central Clinical Hospital of the Ministry of Interior, Warsaw, Poland

Adv Dermatol Allergol 2018; XXXV (3): 267-273

DOI: https://doi.org/10.5114/ada.2018.76222
\end{abstract}

\begin{abstract}
Introduction: Cesarean section affects the process of colonization by bacteria transferred from the mother's skin and hospital bacteria, which in turn contributes to development of allergic conditions.

Aim: To assess selected risk factors, including the mode of delivery, parity, and the role of genetic factors for the development of allergic rhinitis and bronchial asthma.

Material and methods: The study was conducted in 18,617 respondents aged 6-7, 13-14, and 20-44 years who completed the ECRHS II and ISSAC questionnaires. Thirty percent of the study population underwent complementary assessments in the form of skin-prick tests, serum IgE levels, lung function tests, and peak nasal inspiratory flow (PNIF). The study is a part of the Epidemiology of Allergic Disorders in Poland (ECAP) study conducted in 8 areas in Poland (Warsaw, Lublin, Bialystok, Gdansk, Poznan, Wroclaw, Katowice, Krakow, and two rural areas - Zamosc and Krasnystaw counties).

Results: Respondents diagnosed with allergic rhinitis were at a significantly higher risk of inheriting the allergic condition if their mother $\left(\mathrm{OR}=2.17 ; 95 \% \mathrm{Cl}: 1.98-2.39, p=2.00 \times 10^{-16}\right)$ or father $(\mathrm{OR}=2.20 ; 95 \% \mathrm{Cl}: 1.96-2.47$; $p=2.00 \times 10^{-16}$ ) suffers from this allergy. Conversely, in the group diagnosed with bronchial asthma, the highest risk of an inherited allergy was observed in situations where maternal (OR $=2.00 ; 95 \% \mathrm{Cl}: 1.57-2.55 ; p=1.69 \times$ $\left.10^{-5}\right)$ or paternal $\left(\mathrm{OR}=1.94 ; 95 \% \mathrm{Cl}: 1.42-2.66 ; p=3.61 \times 10^{-5}\right)$ grandparent was affected. Moreover, the risk of developing allergic rhinitis depended on the mode of delivery: i.e. it was higher for a Cesarean section $(O R=1.20$; $95 \% \mathrm{Cl}: 1.01-1.43 ; p=0.04)$ than vaginal delivery $(\mathrm{OR}=0.88 ; 95 \% \mathrm{Cl}: 0.78-0.99 ; p=0.03)$. The higher the number of siblings, the lower the risk of allergic rhinitis.

Conclusions: Allergy risk factors, especially those predisposing to allergic rhinitis, include not only genetic factors but also the mode of delivery: vaginal delivery or Cesarean section.
\end{abstract}

Key words: Cesarean section, allergic rhinitis, bronchial asthma.

\section{Introduction}

Due to their impact on public health, allergic disorders are a serious concern in modern medicine. Estimated $40 \%$ of the general population in Poland is affected with an allergy; with 25\% diagnosed with allergic rhinitis (AR); $5 \%$ with bronchial asthma (BA) including 12\% of those manifesting asthma-like symptoms; $9 \%$ diagnosed with atopic dermatitis; $2.1-6.7 \%$ with urticaria, and $13 \%$ with a food allergy [1]. The common AR, defined as "a clinically overt disorder of the nose, developing following an allergen exposure as a result of IgE-mediated nasal mucosal inflammation" [2], results in a lower quality of life, contributes to sleep disturbances, and lowers the work/school productivity. The risk of concomitant conditions such as conjunctivitis, otitis, sinusitis, or BA generates additional costs for the healthcare system. The following have been implicated in the development of allergic conditions: environmental factors, hereditary transfer of atopy, and a role of other factors enhancing

Address for correspondence: Edyta Krzych-Fałta MD, Unit of Environmental Hazard Prevention and Allergology, Faculty of Health Science, Medical University of Warsaw, 1a Banacha St, 02-097 Warsaw, Poland, phone: +48 22599 10 40, fax: +48 2259920 42, e-mail: e.krzych@gmail.com

Received: 30.01.2017, accepted: 13.04.2017. 
inflammatory reaction, such as history of infections, especially during childhood (Strachan's hygiene hypothesis [3]) or the mode of delivery. Unlike vaginal delivery, Cesarean section deprives the child of exposure to Lactobacillus and Bifidobacterium, as well as Bacteroides, Cladosporium, and Eubacterium spp. [4, 5], which measurably regulate intestinal microbiota in the early period of the child's life, and thus affects the development of the newborn's immune system. Delivery via Cesarean section affects the process of colonization by bacteria transferred from the mother's skin and "hospital" (non-physiological) bacteria, which results in a disrupted balance between Th1 and Th2 cells and inflammatory response stimulation, which in turn contributes to development of allergic conditions, including $A R$ and BA [5-7].

\section{Aim}

The purpose of this study was to assess selected risk factors, including the mode of delivery, parity, and the role of genetic factors in AR and BA development.

\section{Material and methods}

Research project No. 6 PO5 2005 C/06572 “Implementation of the system for prevention and early diagnosis of allergic disorders in Poland" (ECAP) evaluated

\section{A}

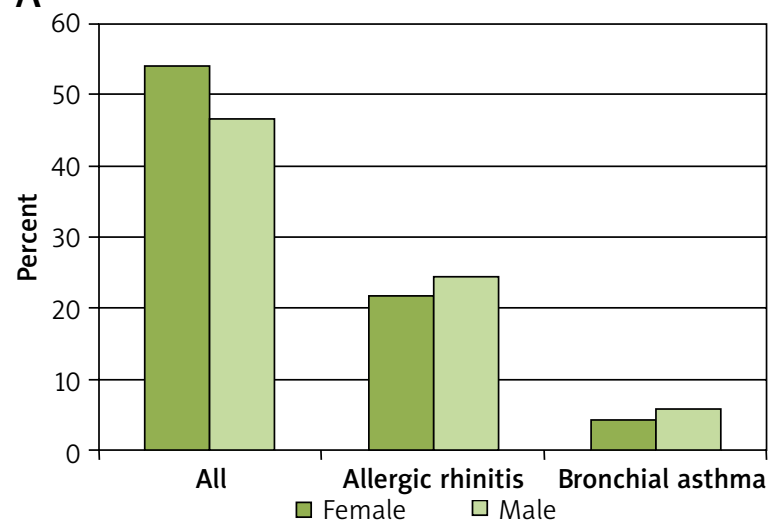

C

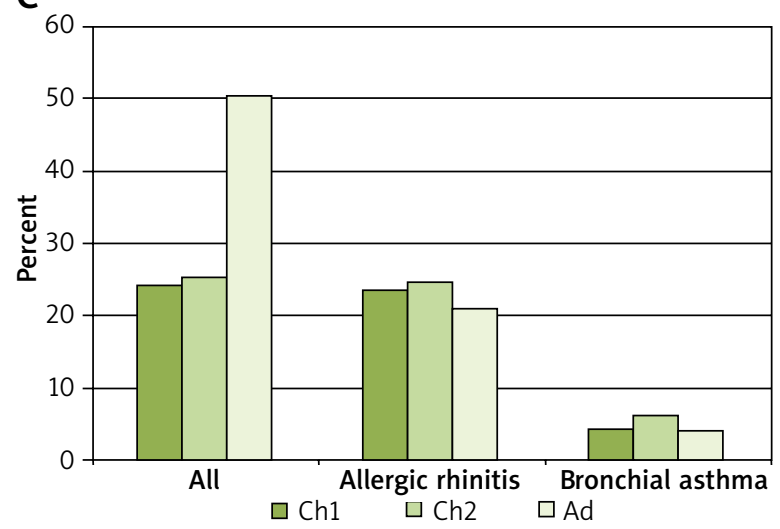

a population of adults aged 20-44 years (ECRHS standard), children aged 6-7 years, and adolescents aged 1314 years (ISAAC standard) residing in eight largest Polish metropolitan areas: Gdansk, Wroclaw, Poznan, Katowice, Krakow, Lublin, Bialystok, and Warsaw, as well as rural regions - Zamosc and Krasnystaw counties (Figure 1).

The ECAP study was conducted in two stages of field research: based on translated and validated ECRHS and ISAAC questionnaires and a clinical examination conducted in $25 \%$ of ECAP questionnaire respondents. A total of 20,454 subjects took part in the first (main) stage, 18,617 of whom passed the final quality testing. These were 10,011 (53.8\%) females, including 2,218 (49.2\%) 6-7-year-olds, 2,275 (48.2\%) 13-14-year-olds, and 5,518 (58.8\%) adults, as well as 8,606 (46.2\%) males, including 2,292 (50.8\%) 6-7-year-olds, 2,446 (51.8\%) 13-14-yearolds, and 3,868 (41.2\%) adults. The study was conducted in 8 Polish regions (Warsaw, Lublin, Bialystok, Gdansk, Poznan, Wroclaw, Katowice, Krakow, and rural areas Zamosc and Krasnystaw counties). Subject distribution was similar across the evaluated regions (Bialystok $n=$ 3,411 (18.3\%), Katowice $n=2,434$ (13.1\%), Lublin $n=1,317$ (7.1\%), Warsaw $n=2,281(12.3 \%)$, Zamosc and Krasnystaw counties $n=2,055$ (11.0\%), Gdansk $n=1,837$ (9.9\%), Krakow $n=1,642$ (8.8\%), Wroclaw $n=1,317$ (7.1\%), Poznan $n=1,218(6.5 \%))$. The second stage involved diagnostics based on the uniform criteria for BA diagnosis

B

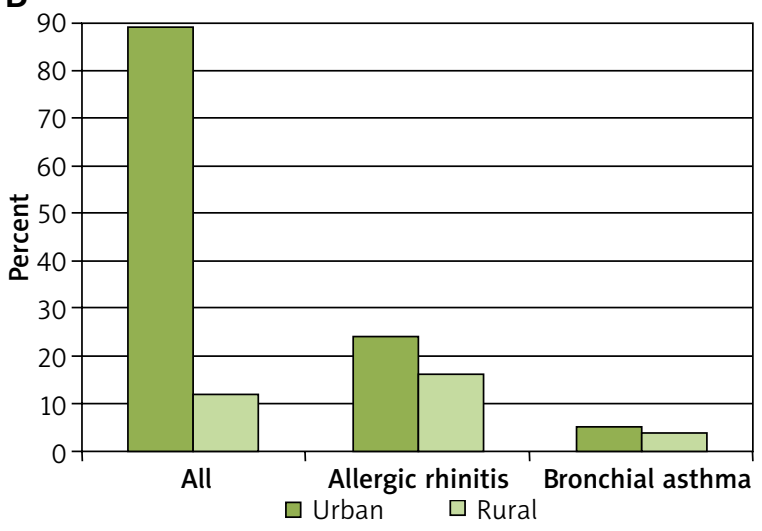

Ch1 - children aged 6-7 years, Ch2 - children aged 13-14 years, Ad - adults.

Figure 1. Study group demographics: A - gender, B - place of residence, $\mathbf{C}$ - years of old 
(Global Initiative for Asthma, GINA), AR (Allergic Rhinitis and its Impact on Asthma, ARIA). Accessory clinical examinations were as follows lung function testing, skinprick testing (Allergopharma) for birch, grasses/cereals, wormwood, Dermatophagoides pteronyssinus and Dermatophagoides farinae, molds (group I); Botrytis cinerea, Cladosporium herbarum, Alternaria tenuis, Curvularia lunata, Fusarium moniliforme, Helminthosporium, and molds (group II); Aspergillus fumigatus, Mucor mucedo, Penicillium notatum, Pullularia pullulans, Rhizopus nigricans, Serpula lacrymans, dog, cat, hazel, alder, rye, ribleaf (Plantago lanceolata), Cladosporium herbarum, Alternaria tenuis) and negative and positive (histamine) controls, peak nasal inspiratory flow (PNIF), immunological tests according to case-report-form (CRF)-based guidelines.

\section{Ethical aspects}

The study was approved by the Ethics Committee/ Institutional Review Board at the Medical University of Warsaw.

\section{Statistical analysis}

The statistical analysis used a logistic regression model to assess significant risk factors in the BA and AR subgroups. Based on this, OR and Wald-type 95\% con- fidence intervals were calculated. The statistical significance of regression parameters was established via Wald test at $p=0.05$.

\section{Results}

\section{Allergic rhinitis and bronchial asthma}

AR has been found to affect nearly $23.6 \%$ of the subject population aged 6-7 years, $24.6 \%$ of $13-14$-yearold adolescents, and $21.0 \%$ of adults. Bronchial asthma was found to affect a considerably lower proportion of children aged 6-7 years (4.4\%), adolescents (6.2\%) and adults (4.0\%). The risk of concomitant AR and BA was found to be considerably lower at $2.4 \%$ for 6-7-yearolds, 3.9\% for adolescents, and 2.2\% for adults out of all subjects. Moreover, both AR and BA were observed to be more common among males $(A R-O R=1.17,95 \% \mathrm{Cl}$ : $1.10-1.26, p=5.04 \times 10^{-6}$; $\mathrm{BA}-\mathrm{OR}=1.36,95 \% \mathrm{Cl}: 1.18-$ $\left.1.55, p=1.10 \times 10^{-5}\right)$.

The most common allergy triggers in subjects diagnosed with AR were Dermatophagoides pteronyssinus and Dermatophagoides farinae (Figure 2). The least common positive tests were due to mold allergens: Alternaria tenuis and Cladosporium herbarum. Positive skin-prick tests were considerably less common among subjects
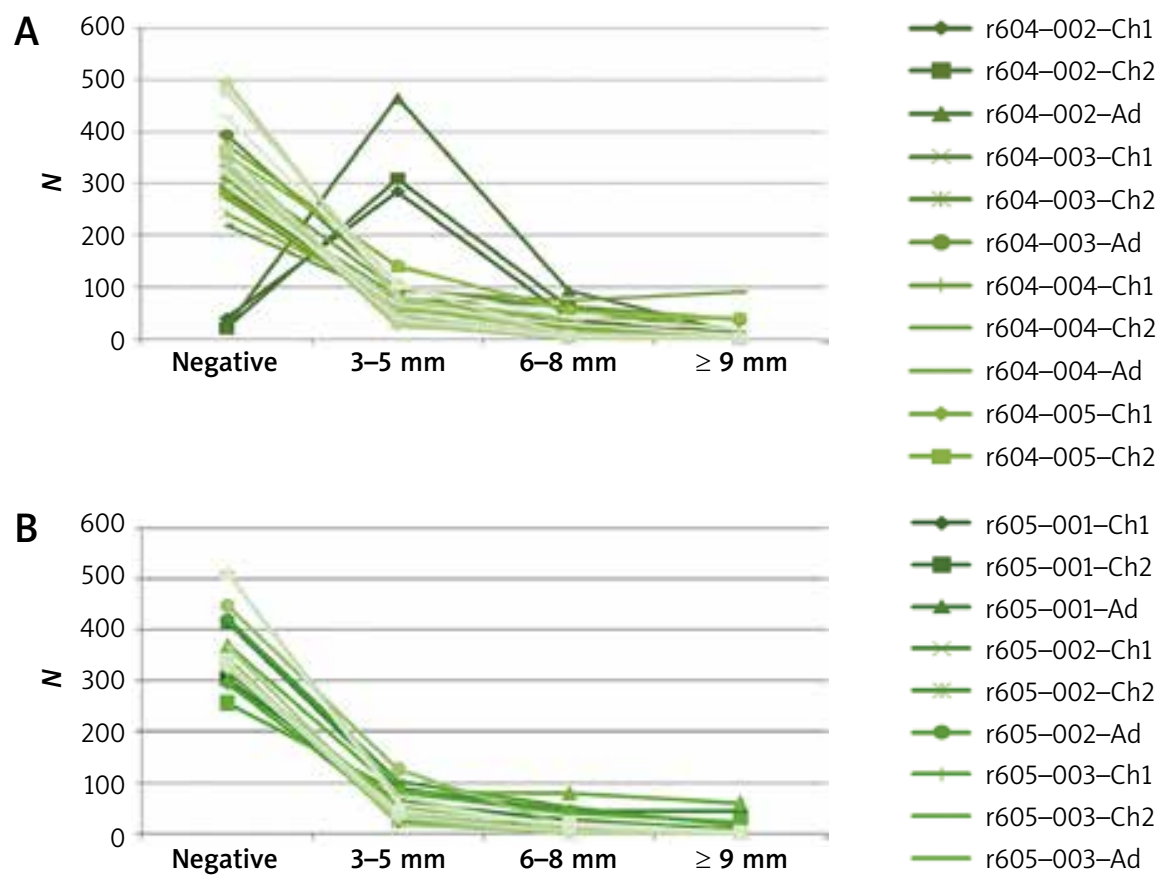

Figure 2. Skin-prick tests in the group diagnosed with allergic rhinitis

Ch1 - children aged 5-6 years, Ch2 - children aged 13-14 years, Ad - adults, Wheal; 604-001 (control), 604-002 (histamine), 604-003 (birch), 604-004 (grasses/ cereals), 604-005 (wormwood), 604-006 (D. pteronyssinus), 604-007 (molds I), 604-008 (molds II), 604-009 (dog), 605-001 (cat), 605-002 (D. farinae), $605-002$ (hazel), 605-003 (alder), 605-004 (rye), 605-005 (ribleaf), 605-006 (Cladosporium), 605-007 (Alternaria), Erythema; 606-001 (control), 606-002 (histamine), 606003 (birch), 606-004 (grasses/cereals), 606-005 (wormwood), 606-006 (D. pteronyssinus), 606-007 (molds I), 606-008 (molds II), $608-009$ (dog), $607-001$ (cat), 607-002 (D. farinae), 607-002 (hazel), 607-003 (alder), 607-004 (rye), 607-005 (ribleaf), 607-006 (Cladosporium), 607-007 (Alternaria). 

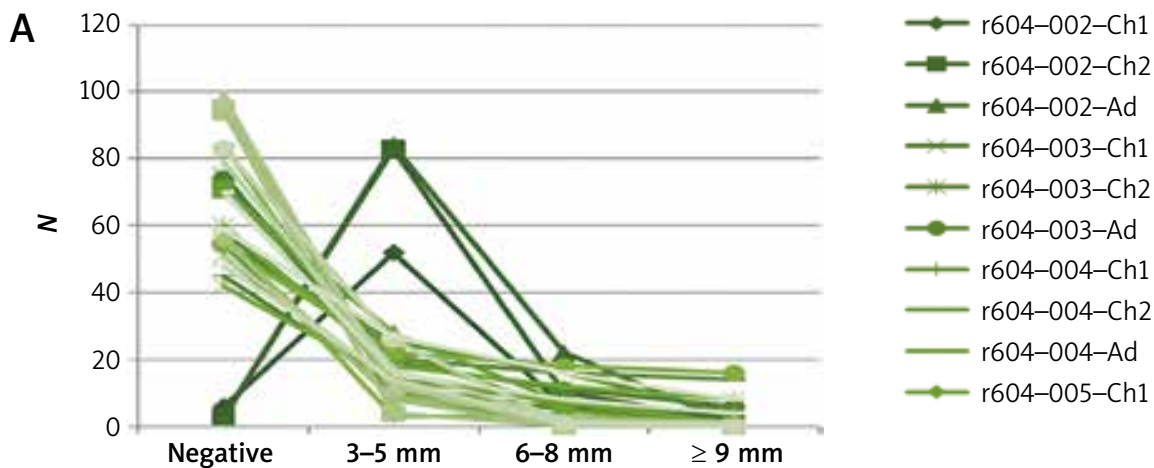

B
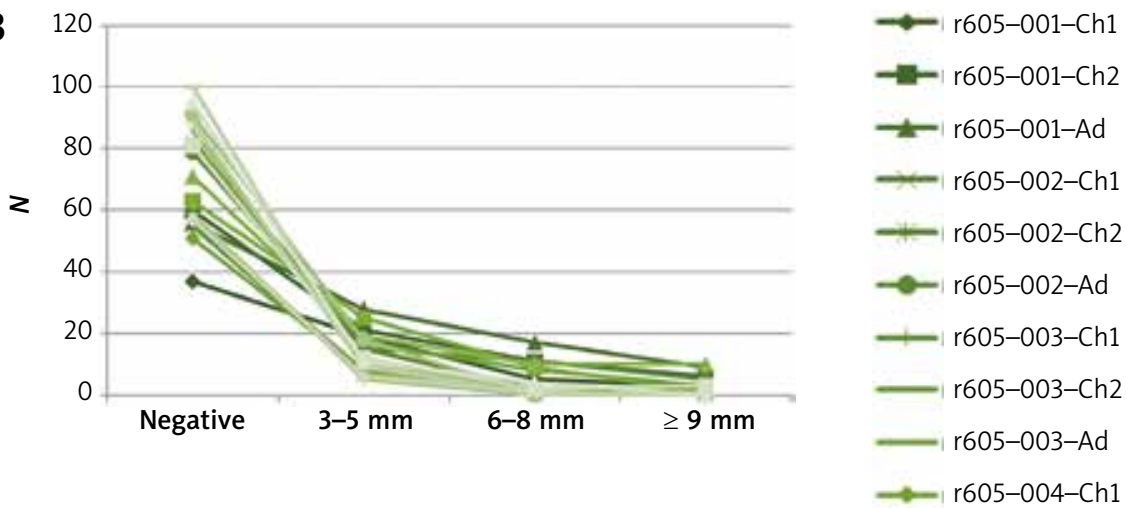

Figure 3. Skin-prick tests in the group diagnosed with bronchial asthma

Ch1 - children aged 5-6 years, Ch2 - children aged 13-14 years, Ad-adults, Wheal; 604-001 (control), 604-002 (histamine), 604-003 (birch), 604-004 (grasses/ cereals), 604-005 (wormwood), 604-006 (D. pteronyssinus), 604-007 (molds I), 604-008 (molds II), 604-009 (dog), 605-001 (cat), $605-002$ (D. farinae), $605-002$ (hazel), 605-003 (alder), 605-004 (rye), 605-005 (ribleaf), 605-006 (Cladosporium), 605-007 (Alternaria); Erythema; 606-001 (control), 606-002 (histamine), 606003 (birch), 606-004 (grasses/cereals), 606-005 (wormwood), 606-006 (D. pteronyssinus), 606-007 (molds I), $606-008$ (molds II), $608-009$ (dog), $607-001$ (cat), 607-002 (D. farinae), 607-002 (hazel), 607-003 (alder), 607-004 (rye), 607-005 (ribleaf), 607-006 (Cladosporium), 607-007 (Alternaria).

diagnosed with BA than among those diagnosed with AR (Figure 3).

\section{Selected risk factors for allergic rhinitis and bronchial asthma}

Subjects with AR were found to be at a significantly higher risk of inheriting an allergic condition if their mother $\left(\mathrm{OR}=2.17,95 \% \mathrm{Cl}: 1.98-2.39, p=2.00 \times 10^{-16}\right)$ or father $\left(\mathrm{OR}=2.20,95 \% \mathrm{Cl}: 1.96-2.47, p=2.00 \times 10^{-16}\right)$ suffers from an allergy. The rates of AR are higher if the subject's siblings are diagnosed with an allergy (OR = $\left.1.54,95 \% \mathrm{Cl}: 1.41-1.69, p=2.00 \times 10^{-16}\right)$, maternal grandparents $\left(\mathrm{OR}=1.65,95 \% \mathrm{Cl}: 1.65-1.42, p=1.55 \times 10^{-16}\right)$ and paternal grandparents $(\mathrm{OR}=1.44,95 \% \mathrm{Cl}: 1.17-1.79$, $\left.p=6.68 \times 10^{-4}\right)$. The highest risk of hereditary allergies in the group of subjects diagnosed with BA were recorded when maternal grandparents $(\mathrm{OR}=2.00,95 \% \mathrm{Cl}$ : $1.57-$ $\left.2.55, p=1.69 \times 10^{-5}\right)$ or paternal grandparents $(\mathrm{OR}=1.94$, $95 \% \mathrm{Cl}: 1.42-2.66, p=3.61 \times 10^{-5}$ ) were diagnosed with an allergy, and a lower risk when those diagnosed with an allergy were the mother $(\mathrm{OR}=1.72,95 \% \mathrm{Cl}: 1.44-2.05$, $\left.p=1.82 \times 10^{-9}\right)$, the father $(\mathrm{OR}=1.69,95 \% \mathrm{Cl}: 1.37-2.07$, $\left.p=7.02 \times 10^{-7}\right)$, or siblings $(\mathrm{OR}=1.31,95 \% \mathrm{Cl}: 1.11-1.56$, $\left.p=1.56 \times 10^{-5}\right)$.

The mode of delivery was found to be a factor indirectly determining the development of AR; with Cesarean section increasing the risk of allergy in comparison to vaginal delivery (Table 1). The ratio of Cesarean sections $(n=802)$ to vaginal deliveries $(n=2,811)$ was roughly $3: 10=802$ vs. $n=2811$. Interestingly, in rural areas (18.7\% of Cesarean sections versus vaginal deliveries while in urban areas this proportion is $22.7 \%$ ), a Cesarean section increases the risk of $A R$ nearly two-fold (OR = $1.85,95 \% \mathrm{Cl}: 1.04-3.27, p=0.004)$ while in urban areas a vaginal delivery proved to be a decidedly preventive factor $(\mathrm{OR}=0.87,95 \% \mathrm{Cl}: 0.76-0.99, p=0.03)$.

A twin pregnancy (whether homozygous or heterozygous) does not play any important role as an allergy predictor or preventive factor. The greater the number of children in a family, the lower the risk of AR in each child, while being the only child increases the risk of allergies, especially $\mathrm{AR}$; OR $=1.27(95 \% \mathrm{Cl}: 1.16-1.39, p=$ $\left.8.17 \times 10^{-8}\right)$. However, the development of BA seems to be unaffected by the means of delivery or a relatively higher number of children (more than 2) in the family. 
Table 1. Selected risk factors in allergy development

\begin{tabular}{lllc}
\hline Risk factor & OR & $95 \% \mathrm{Cl}$ & $P$-value \\
\hline Allergic rhinitis & & & 0.03 \\
\hline Mode of delivery; vaginal & 0.88 & $0.78-0.99$ & 0.04 \\
\hline Mode of delivery; Cesarean section & 1.20 & $1.01-1.43$ & $8.17 \times 10^{-8}$ \\
\hline Number of children: 1 & 1.27 & $1.16-1.39$ & $<0.001$ \\
\hline Number of older siblings: 1 & 0.87 & $0.81-0.95$ & $4.48 \times 10^{-7}$ \\
\hline Number of older siblings: 2 & 0.74 & $0.66-0.83$ & 0.02 \\
\hline Number of older siblings: 3 & 0.81 & $0.68-0.98$ & 0.09 \\
\hline Number of older siblings: 4 & 0.77 & $0.54-1.04$ & 0.04 \\
\hline Number of older siblings: 5 & 0.60 & $0.37-0.98$ & 0.01 \\
\hline Number of older siblings: 6 & 0.27 & $0.10-0.76$ & 0.03 \\
\hline Bronchial asthma & & $0.72-0.72$ & $<0.001$ \\
\hline Number of older siblings: 1 & 0.84 & $0.54-0.87$ & 0.15 \\
\hline Number of older siblings: 2 & 0.68 & $0.52-1.10$ & 0.37 \\
\hline Number of older siblings: 3 & 0.76 & $0.41-1.39$ & 0.18 \\
\hline Number of older siblings: 4 & 0.76 & $0.14-1.44$ & $0.19-3.18$ \\
\hline Number of older siblings: 5 & 0.46 & & 0.72 \\
\hline Number of older siblings: 6 & 0.77 & & \\
\hline
\end{tabular}

\section{Discussion}

Depending on the degree of kinship, a potential risk of allergic conditions is $25-30 \%$. Interestingly, this study demonstrated a two-fold higher risk of inheriting atopy from the mother and father in the case of AR, and from both maternal and paternal grandparents in the case of BA. We showed that the effect of environmental factors on developing atopic conditions differs significantly depending on genetic predisposition. Here, a particularly important role is attributed to mutations of filaggrin (amino acid precursor of 35-37 kDa; a component of natural moisturizing factor), especially mutations 2282del4 and R501X. Ponińska et al. in a study on the role of filaggrin (2282del4) in allergic condition inheritance in a population of 3,802 , estimated the risk of concomitant atopic dermatitis $(A D)(O R=2.01,95 \% \mathrm{Cl}: 1.20-3.36$; $p=0.007), \operatorname{AR}(\mathrm{OR}=1.69,95 \% \mathrm{Cl}: 1.12-2.54, p=0.011)$, atopic asthma (OR $=2.22,95 \% \mathrm{Cl}: 1.24-3.96, p=0.006)$ with the presence of filaggrin and no involvement of IgEdependent allergic reaction (slgE) [8].

One particularly interesting factor predisposing to the allergic condition development is the mode of delivery. According to the World Health Organization guidelines, only $10-15 \%$ of all deliveries should be via Cesarean section when medically indicated. Currently, in affluent countries of Europe and North America, 20-30\% of all deliveries are performed via Cesarean section. The proportion of Cesarean sections in Poland is approximately $30 \%$ of all deliveries, which is consistent with the mean proportion in Europe. The proportion of preterm labor in Poland is approximately $7 \%$ of all deliveries [9]. Currently, according to a resolution by the Head of the Polish National Health Fund (NFZ) on June 30, 2016, the cost of a vaginal delivery and that of Cesarean section within Diagnosis-Related Groups (DRG) was assigned to group No. N01: "Delivery" and equals 33 points. At the same time, based on the resolution mentioned above, preterm labor was classified as DGR No. N02: "Multiple or preterm labor" and estimated at 46 points. This point estimate seems to be important because of the reports, which follow, on the importance of preterm labor in terms of the risk of bronchial asthma in children under 3 years of age, whereas a delivery via Cesarean section can increase the risk of asthma symptoms. The data on preterm labor rates suggest a greater burden on the healthcare system for two reasons: higher costs incurred by the NFZ resulting from the course of preterm labor (hence, the 13-point higher estimate in comparison to that of a vaginal delivery) and, what is more important, further costs constituting long-term burden on the Polish healthcare system resulting from treatment of people affected with allergic conditions (including BA), which is due to both preterm labor and Cesarean section. 
A review of the literature revealed particularly salient (for the purpose of this discussion) reasons for the theory documenting the increasing allergy rates associated with this group of risk factors, due to qualifying Cesarean section as a "marker of sterile environment" [10]. According to the hygiene hypothesis, the effect of sterile environment, especially during the first years of life, negatively affects the Th1 and Th2 lymphocyte balance [11]. The preventive effect suggested by the hygiene hypothesis is more pronounced in families with negative history of allergies. Undoubtedly the effect of and colonization by physiological bacteria, which are transferred from the mother to the child during a vaginal delivery affects the intestinal balance of the newborn child. The COPSAC 2010 (Copenhagen Prospective Studies on Asthma in Childhood $_{2010}$ ) cohort study by Stokholm et al. in a group of 700 children $(12 \%$ born via a Cesarean section due to medical indications and $9 \%$ elective) demonstrated colonization of the gastrointestinal tract by Citrobacter freundii, Clostridium species, Enterobacter cloacae, Enterococcus faecalis, Klebsiella oxytoca, Klebsiella pneumoniae, and Staphylococcus aureus already on the first day of life, whereas the children born via a vaginal delivery exhibited colonization by Escherichia coli. At the same time, there were no significant differences in terms of the process of bacterial colonization of the respiratory system in newborns born via a vaginal delivery vs. Cesarean section. The authors suggested a correlation between disturbances in bacterial colonization, especially in the gastrointestinal tract, and the development of the immune system, the mode of delivery and the risk of developing allergic conditions depending on the age of the study population reported in the relevant literature often corresponds with the 'allergic march' [12]. A cohort study by Papathoma et al. in a group of 233 individuals demonstrated that factors, such as Cesarean section $(\mathrm{OR}=3.15 ; 95 \% \mathrm{Cl}: 1.14-8.70)$, atopic dermatitis (OR = 3.01; 95\% Cl: 1.18-7.80), positive family history of atopic conditions ( $\mathrm{OR}=4.33$; $95 \% \mathrm{Cl}: 1.73-12.1)$, and mother's age during pregnancy $(\mathrm{OR}=1.57 ; 95 \% \mathrm{Cl}: 1.07-2.37)$ are significant risk factors for food allergy development [13]. This is consistent with the findings by Edwards et al., who evaluated a group of 545 preterm children (born in 37-38 week of gestation) versus term infants and demonstrated a significant effect of Cesarean section on the development of bronchial wheezing [14]. Huang et al. estimated the potential risk of developing BA in a group of children born via Cesarean section on a statistically significant level (OR $=1.16$; 95\% Cl: 1.14-1.29) [15]. Whereas, Wang et al. estimated the risks of developing BA with respect to a number of complex risk factors, the most important of which was preterm labor $(\mathrm{OR}=1.72 ; 95 \% \mathrm{Cl}$ : 1.42-2.08), which increases the risk of BA in children under the age of 3 years. In the group of children aged $3-5$ years, it was sex $(\mathrm{OR}=1.18 ; 95 \% \mathrm{Cl}: 1.03-1.35)$, low birth weight $(\mathrm{OR}=1.69 ; 95 \% \mathrm{Cl}: 1.17-2.44)$, and Cesarean section $(\mathrm{OR}=1.26 ; 95 \% \mathrm{Cl}: 1.10-2.45)$ that significantly increased the risk of asthma symptoms [16].

Reports on the effects of the mode of delivery on the development of conditions such as AR are contradictory. Freitas et al. estimated a nearly 5 -fold higher risk of rhinitis in a group of children born via Cesarean section (OR = 5.2, 95\% Cl: 1.2-21.9) [17]. This study also demonstrated a significant effect of this mode of delivery on the development of symptoms associated with AR. Conversely, a study in a group of Korean children $(n=279)$ aged up to 16 years, $179(62.6 \%)$ of which were born via vaginal delivery and 100 (37.4\%) via Cesarean section demonstrated no significant differences in terms of allergic conditions: BA: 0.76 (0.37-1.57); AR: 1.14 (0.61-2.10), or AD: 1.01 (0.59-1.71) [18]. Moreover, epidemiological studies showed a reverse correlation between atopic diseases and the number of children in the family. Undoubtedly, a higher number of siblings corresponds with higher rates of infections transferred via various routes, which have a protective effect against the development of allergic conditions [3]. These findings are consistent with those of Karmaus et al. who demonstrated a preventive effect against allergic diseases, which increased with the number of older siblings, with OR values 0.44 for hay fever, 0.66 for atopic eczema, and 0.72 for asthma [19].

\section{Conclusions}

Factors predisposing to the development of allergies, especially AR, included hereditary transmission of atopy and the means of delivery. Unlike vaginal deliveries, Cesarean-section deliveries increases the risk of asthmatic symptoms in the child. The larger the family, the lower the risk of allergies, especially AR in each child. Having one sibling (a brother or a sister) "equalizes" the effect of the means of delivery in terms of the risk of developing $A R$ and $A B$ (Table 1).

\section{Conflict of interest}

The authors declare no conflict of interest.

\section{References}

1. Samoliński B, Raciborski F, Lipiec A, et al. Epidemiologia chorób w Polsce (ECAP). Alergol Pol/Pol J Allergol 2014; 1: 10-8.

2. Samoliński B, Rapiejko P, Krzych-Fałta E, et al. Standards of nasal provocation test. Post Dermatol Alergol 2010; 27: 149-61.

3. Strachan PD. Hay fever, hygiene and household size. BMJ 1989; 299: 1259-60.

4. Janczewska I, Domżalska-Popadiuk. Znaczenie kolonizacji bakteryjnej przewodu pokarmowego noworodków donoszonych urodzonych drogą cięcia cesarskiego. Ann Acad Med Gedan 2014; 44: 99-104.

5. Biasucci G, Benenati B, Morelli L, et al. Cesarean delivery may affect the early biodiversity of intestinal bacteria. J Nutr 2008; 138: 1796S-800S. 
6. Biasucci G, Rubini M, Riboni S, et al. Mode of delivery affects the bacterial community in the newborn gut. Early Human Dev 2010; 86 Suppl 1: S13.

7. van Nimwegen FA, Penders J, Stobberingh E, et al. Mode and place of delivery, gastrointestinal microbiota, and their influence on asthma and atopy. J Allergy Clin Immunol 2011; 128: 948-55.

8. Ponińska J, Samoliński B, Tomaszewska A, et al. Filaggrin gene defects are independent risk factors for atopic asthma in a Polish population: a study in ECAP cohort. PLoS One 2011; 6: e16933.

9. Rocznik Demograficzny, Główny Urząd Statystyczny, Warsaw 2014; 350.

10. Negele K, Heinrich J, Borte M, et al. Mode of delivery and development of atopic disease during the first years of life. Pediatr Allergy Immunol 2004; 15: 48-54.

11. Duczmal E, Bręberowicz A, Duczmal T. Wpływ wybranych czynników na wystąpienie chorób alergicznych w badaniu kohorty urodzeniowej. Alergia Astma Immunol 2011; 16: 96 104.

12. Stokholm J, Thorsen J, Chawes BL, et al. Cesarean section changes neonatal gut colonization. J Allergy Clin Immunol 2016; 138: 881-9.e2.

13. Papathoma E, Triga M, Fouzas S, et al. Cesarean section delivery and development of food allergy and atopic dermatitis in early childhood. Pediatr Allergy Immunol 2016; 27: 419-24.

14. Edwards MO, Kotecha SJ, Lowe J, et al. Early-term birth is a risk factor for wheezing in childhood: a cross-sectional population study. J Allergy Clin Immunol 2015; 136: 581-7.e2.

15. Huang L, Chen Q, Zhao Y, et al. Is elective cesarean section associated with a higher risk of asthma? A meta-analysis. J Asthma 2015; 52: 16-25.

16. Wang Q, Xu C, Xu D, et al. Risks on asthma among city children in China: a nationwide case-control study. Zhonghua Liu Xing Bing Xue Za Zhi 2014; 35: 237-41.

17. Freitas MS, de Córdoba Lanza F, Monteiro JC, et al. Prevalence of rhinitis and associated factors in schoolchildren who live in the Amazon islands. J Rhinol Allergy 2016; 30: 79-82.

18. Park YH, Kim KW, Choi BS, et al. Relationship between mode of delivery in childbirth and prevalence of allergic diseases in Korean children. Allergy Asthma Immunol Res 2010; 2: 28-33.

19. Karmaus W, Botezan C. Does a higher number of siblings protect against the development of allergy and asthma? A review. J Epidemiol Community Health 2002; 56: 209-17. 